\title{
The Use of Glucose Syrup as Product of Selulosa Hidrolyze from the Jackfruit Rags (Artocarpus heterophylus Lamk) as Sweetner on Candies Production from the Coconut Plam (Cocos Nucifera $L$ )
}

\section{Pemanfaatan Sirup Glukosa Hasil Hidrolisa Selulosa dari Dami Nangka (Artocarpus heterophylus Lamk) sebagai Pemanis pada Pembuatan Manisan dari Buah Kelapa (Cocos Nucifera $L$ )}

\author{
Nurmala Sari ${ }^{1,2)^{*}}$ \\ ${ }^{1}$ Fakultas Farmasi Universitas Tjut Nyak Dhien \\ Jl.Gatot Subroto No.28 Medan, Indonesia \\ 2Jurusan Kimia FMIPA Universitas Sumatera Utara \\ J. Bioteknologi No.1 Kampus USU Medan 20155 \\ Email :nurmalasari2705@gmail.com
}

\begin{abstract}
Research on the influence of polysaccharides from the jackfruit rags (Artocarpus Heterophyllus Lamk) on the content of glucose syrups on hydrolyzing with $\mathrm{HCl} 30 \%$ has been done. A sample has got with simple random sampling. The cellulose was isolated from the seeds of rags. The cellulose was hydrolyzed by $\mathrm{HCl}$ $30 \%$ to produce glucose syrups. The content was analyzed by the Nelson-Somogyi method and calculated by regression analysis. The results of analysis show that the content of glucose syrups from the cellulose from the jackfruit rags were $2.47 \%$.
\end{abstract}

Keywords: cellulose, jackfruit rags, glucose syrups, Hydrolysis

\begin{abstract}
ABSTRAK
Telah dilakukan penelitian mengenai pengaruh polisakarida dalam dami nangka terhadap kandungan sirup glukosa melalui proses hidrolisis menggunakan $\mathrm{HCl} 30 \%$. Pengambilan sampel dilakukan dengan metode acak sederhana. Sampel berupa selulosa yang diisolasi dari dami nangka. Selulosa kemudian dihidrolisis dengan $\mathrm{HCl} \mathrm{30 \%} \mathrm{untuk} \mathrm{menghasilkan} \mathrm{sirup} \mathrm{glukosa.} \mathrm{Kadar} \mathrm{glukosa} \mathrm{dianalisis} \mathrm{dengan} \mathrm{menggunakan}$ metode Nelson-Somogyi dan dihitung dengan analisis regresi. Dari hasil penelitian diperoleh sirup glukosa dari selulosa dami nangka dengan kadar glukosa sebesar 2,47\%.
\end{abstract}

Kata Kunci: Selulosa, Dami nangka, sirup glukosa, hidrolisis 


\section{PENDAHULUAN}

Selulosa adalah jenis polisakarida yang banyak terdapat di alam yang disusun oleh satuan D-glukosa (Sulaiman, 1996). Selulosa yang terdapat di alam yaitu tumbuhan yang dapat dihidrolisis oleh asam ataupun enzim, menghasilkan monosakarida atau turunan monosakarida. (Girindra,1990). Didalam tubuh manusia, selulosa tidak dapat dicerna karena di dalam tubuh manusia tidak mempunyai enzim yang dapat meguraikan selulosa. Tetapi ternyata selulosa dapat dimanfaatkan, dimana dengan menggunakan asam encer, selulosa tidak dapat dihidrolisis, tetapi oleh asam dengan konsentrasi tinggi yaitu secara kimiawi menggunakan $\mathrm{HCl} 30 \%$ dapat dihidrolisis menjadi D-glukosa (Poedjiadi,1994).

Disamping buah dan biji, dami nangka merupakan bagian nangka yang sering terbuang dan merupakan limbah, padahal dami nangka mempunyai porsi yang cukup besar yaitu sekitar $40-50 \%$ dari limbah yang dihasilkan. Dami nangka memiliki kandungan serat dua kali lebih besar dibandingkan daging buah. Berdasarkan analisa bahan baku yaitu dami nangka mengandung pektin yang cukup tinggi yakni sekitar $2.38 \%$ dan daging buah nangka sekitar $1.56 \%$ (Sugiarta,2003 dalam Tarmizi, 2011). Namun, kebanyakan masyarakat membuang dami nangka begitu saja, karena banyak masyarakat yang belum mengetahui bahwa dami nangka mengandung pektin sehingga dapat dijadikan sebagai produk olahan pangan.

Sejumlah penelitian yang telah dilakukan untuk hidrolisis selulosa menjadi glukosa, yaitu sirup glukosa dari hasil hidrolisis kulit buah kuini adalah 15.96\% (Sari,F.M., 2012), sirup glukosa dari hasil hidrolisis kulit buah sukun adalah $10.66 \%$ (Pratiwi,2011), sirup glukosa dari hasil hidrolisis rumput gajah adalah $12.53 \%$ (wijayanti,2005). Ketiga penulis tersebut menggunakan metode penentuan kadar glukosa yang sama dengan metode dalam penelitian ini

Jadi, limbah-limbah yang mengandung selulosa, ternyata dapat dihidrolisis menjadi sirup glukosa, sirup glukosa dapat dimanfaatkan untuk pembuatan manisan dengan menggunakan gula pasir. Jadi dengan adanya pelestarian lingkungan bertujuan untuk memanfaatkan limbah-limbah yang mengandung selulosa yang terdapat di tumbuhan
Salah satu cara yang dapat membantu penyediaan gula di Indonesia adalah membuat sirup glukosa (gula cair) dari selulosa. Sirup glukosa merupakan larutan yang diperoleh dari proses hidrolisis. Perbedaannya dengan gula pasir atau sukrosa yaitu sukrosa merupakan gula disakarida, terdiri atas ikatan glukosa dan fruktosa, sedangkan sirup glukosa adalah monosakarida, terdiri atas satu monomer yaitu glukosa (pratiwi, 2011).

Industri makanan dan minuman memiliki kecendrungan untuk menggunakan sirup glukosa dibandingkan sukrosa (gula pasir), diantaranya sirup glukosa tidak mengkristal seperti halnya sukrosa jika dilakukan pemanasan pada suhu tinggi dan sirup glukosa memilik rasa manis yang tinggi (Cakebread,1975) (Dziedzic and Kearsley, 1984).

Berdasarkan penelitian terdahulu, yang telah dilakukan sebelumnya mengenai pemanfaatan sirup glukosa dari hasil hidrolisis selulosa yang diisolasi dari berbagai bagian tanaman, seperti biji, kulit buah atau ampas daging buah, maka peneliti juga ingin memanfaatkan limbah produksi buah, yaitu dami nangka. Dimana dami nangka sendiri kurang dimanfaatkan oleh masyarakat dan dianggap sebagai limbah. Salah satu upaya pemanfaatan dami nangka ini adalah dengan cara menghidrolisis dami nangka sehingga diperoleh larutan glukosa yang dapat digunakan untuk keperluan pangan industri dan rumah tangga.

Berdasarkan uraian diatas peneliti tertarik untuk mengelolah dami nangka menjadi sirup glukosa sebagai pengganti gula pasir untuk pembuatan manisan dengan perbandingan antara gula pasir dengan sirup glukosa $(1: 0,1: 1,1: 2$, dan 1:3).

\section{METODOLOGI PENELITIAN}

\section{Alat}

Alat yang digunakan dalam penelitian ini adalah : Spektofometer UV Visible, Neraca Analitis, labu takar, gelas beaker, labu erlenmeyer, tabung reaksi, corong, thermometer, oven, pendingin bola, tanur, incubator, desikator dan crusibel.

\section{Bahan}

Bahan yang digunakan adalah buah kelapa, dami nangka, $\mathrm{C}_{6} \mathrm{H}_{12} \mathrm{O}_{6}, \quad \mathrm{Na}_{2} \mathrm{CO}_{3}, \quad \mathrm{KNaC}_{4} \mathrm{H}_{4} \mathrm{O}_{6} 4 \mathrm{H}_{2} \mathrm{O}$, $\mathrm{NaHCO}_{3}, \quad \mathrm{Na}_{2} \mathrm{SO}_{4}$, 
$\mathrm{CuSO}_{4.5} \mathrm{H}_{2} \mathrm{O}, \mathrm{H}_{2} \mathrm{SO}_{4},\left(\mathrm{NH}_{4}\right)_{6} \mathrm{Mo}_{7} \mathrm{O}_{24} .4 \mathrm{H}_{2} \mathrm{O}$,

$\mathrm{Na}_{2} \mathrm{HAsO}_{4} .7 \mathrm{H}_{2} \mathrm{O}, \mathrm{NaOH}, \mathrm{HCl}_{(\mathrm{p})}$, Etanol, Na-sitrat dan akuades.

\section{PROSEDUR PENELITIAN}

\section{Isolasi dan Analisis Kadar selulosa dari dami nangka}

Sebanyak 500 gr dami nangka dikeringkan pada suhu $110^{\circ} \mathrm{C}$. Dami nangka yang telah kering kemudian dihaluskan dan ditimbang. Ditambahkan $200 \mathrm{ml}$ alcohol 96\%. Lalu, ditambahkan $200 \mathrm{ml}$ $\mathrm{H}_{2} \mathrm{SO}_{4} 1.25 \mathrm{~N}$ direfluks selama 30 menit lalu disaring. Residu dicuci dengan akuades panas sampai pH netral. Kemudian ditambahkan $200 \mathrm{ml}$ $\mathrm{NaOH} 1.25 \mathrm{~N}$ dan direfluks selama 30 menit. Residu dicuci dengan akuades panas sampai $\mathrm{pH}$ netral. Kemudian dikeringkan dioven pada suhu $110^{\circ} \mathrm{C}$ dan ditimbang. Diambil $5 \mathrm{~g}$, lalu diabukan pada suhu $600^{\circ} \mathrm{C}$ selama 3 jam, dan ditimbang.

\section{Hidrolisa Selulosa Dami Nangka dan Uji Gula Reduksinya secara kualitatif}

Ditimbang $5 \mathrm{gr}$ selulosa kedalam labu Erlenmeyer kemudian ditambahkan $4 \mathrm{ml} \mathrm{HCl} \mathrm{30 \% ,}$ ditutup dengan alumunium foil dan didiamkan dipenangas air selama 30 menit lalu didinginkan. Lalu ditambahkan $200 \mathrm{ml}$ akuades dan dipanaskan di atas api selama 1 jam lalu didinginkan. Kemudian ditambah $\mathrm{NaOH} 3 \%$ hingga $\mathrm{pH}$ netral lalu disaring, sebanyak $1 \mathrm{ml}$ filtrat dimasukkan kedalam tabung reaksi kemudian ditambahkan 5 $\mathrm{ml}$ larutan benedict dan dipanaskan sampai terbentuk endapan merah bata (Pratiwi, 2011)

\section{Pengukuran Panjang Gelombang Maksimum Larutan Glukosa Standar}

Ditimbang $20 \mathrm{mg}$ glukosa anhidrat dan dilarutkan dengan akuades sampai volume $100 \mathrm{ml}$ (larutan glukosa $0.2 \mathrm{mg} / \mathrm{ml}$ ). Dipipet $25 \mathrm{ml}$ larutan lalu diencerkan dengan akuades sampai volume $100 \mathrm{ml}$ (larutan glukosa $0.05 \mathrm{mg} / \mathrm{ml}$ ). Dipipet $1 \mathrm{ml}$ larutan glukosa $0.05 \mathrm{mg} / \mathrm{ml}$ kedalam tabung reaksi, lalu ditambahkan $1 \mathrm{ml}$ pereaksi Nelson. Kemudian ditutup dengan kapas dan dipanaskan pada waterbath sampai mendidih selama 30 menit lalu didinginkan. Kemudian, ditambahkan $1 \mathrm{ml}$ larutan arsenomolibdat lalu dikocok hingga semua endapan larut. Ditambahkan $7 \mathrm{ml}$ akuades lalu kocok hingga homogen. Diukur serapan panjang gelombang pada 400-800 nm. (Pratiwi,2011 dan
Sari,F.M.,2012). Maka diperoleh panjang gelombang maksimum yang didapat $(761 \mathrm{~nm})$

\section{Penyiapan Kurva Standar Glukosa}

Disiapkan larutan glukosa standar dengan variasi konsentrasi dari $0.02-0.18 \mathrm{mg} / \mathrm{ml}$. Ditambahkan $1 \mathrm{ml}$ larutan Nelson kemudian dipanaskan selama 30 menit dan didinginkan. Ditambahkan $1 \mathrm{ml}$ larutan arsenomolibdat lalu dikocok hingga semua endapan larut. Ditambahkan $7 \mathrm{ml}$ akuades lalu kocok hingga homogen. Diukur serapannya pada panjang gelombang $761 \mathrm{~nm}$. Kemudian dibuat kurva standar yang menunjukkan hubungan antara konsentrasi glukosa standard dan absorbansi (Pratiwi,2011 dan Sari,F.M.,2012).

\section{Analisa Kadar Glukosa Sampel}

Dipipet $1 \mathrm{ml}$ filtrat hasil hidrolisa dami nangka lalu diencerkan dalam labu ukur $50 \mathrm{ml}$ dan diambil $1 \mathrm{ml}$ untuk dianalisa. Ditambahkan $1 \mathrm{ml}$ larutan Nelson kemudian dipanaskan hingga mendidih selama 30 menit dan didinginkan. Ditambahkan $1 \mathrm{ml}$ larutan arsenomolibdat lalu dikocok. Kemudian ditambahkan $7 \mathrm{ml}$ akuades dan Diukur serapannya pada panjang gelombang 761 $\mathrm{nm}$ sehingga dapat dihitung kadar gula reduksinya (Pratiwi,2011 dan Sari,F.M.,2012).

\section{Pembuatan Manisan Kelapa}

Disortasi buah kelapa, setelah itu dicuci hingga bersih dan kulitnya dikupas. Potong buah kelapa menjadi 4 (empat ) bagian yang sama besarnya. Direndam potongan buah dalam larutan kapur 10\% selama 1 jam, rendam kembali buah kelapa dalam larutan garam 10\% selama 12 jam. Selanjutnya lakukan blanching selama 3 menit. Tiriskan dan cuci dengan air dingin yang mengalir, setelah ditiriskan kemudian buah direndam dalam campuran larutan gula pasir dan larutan glukosa yang telah dpanaskan dan konsentrasinya divariasikan dengan perbandingan yang $(1: 0,1: 1$, $1: 2$, dan $1: 3)$.

\section{Penentuan Nilai Organoleptik}

Uji ini meliputi warna, bau, rasa dan tekstur yang ditentukan dengan uji kesukaan oleh 15 orang panelis, dimana para panelis bukan perokok dan sebelum mencicipinya diharuskan minum air putih terdahulu. Uji ini ditentukan dengan skala hedonik, sebagai berikut ; 
Tabel 1. Penentuan Uji Nilai Organoleptik

\begin{tabular}{|c|c|}
\hline $\begin{array}{c}\text { Uji Kesukaan (Skala } \\
\text { Hedonik) }\end{array}$ & $\begin{array}{c}\text { Skala } \\
\text { Numerik }\end{array}$ \\
\hline Amat Sangat Suka & 5 \\
\hline Sangat Suka & 4 \\
\hline Suka & 3 \\
\hline Kurang Suka & 2 \\
\hline Tidak Suka & 1 \\
\hline
\end{tabular}

\section{HASIL DAN PEMBAHASAN}

\section{Isolasi selulosa dan Analisa kadar selulosa dari dami nangka}

Didalam analisa penentuan serat kasar yaitu mengandung selulosa, lignin dan zat lain yang belum dapat diidentifikasi dengan pasti. Menurut (pratiwi,2011) langkah-langkah metode yang dilakukan dalam analisa isolasi sampel yang mengandung serat kasar yaitu metode defatting, metode destruksi, metode delignifikasi dan pangabuan.

Selulosa dari hasil isolasi dami nangka menggunakan langkah-langkah yang dilakukan dalam analisa yaitu pertama menggunakan metode defatting yaitu menghilangkan lemak yang terkandung dalam sampel yaitu dami nangka dengan menggunakan pelarut etanol. Serat kasar yaitu mengandung selulosa yang sangat penting dalam penilaian kualitas bahan makanan karena menentukan nilai gizi bahan makanan tersebut (Sudarmadji.S.,1989). Langkah kedua yaitu metode destruksi, dimana pada tahap ini sampel dami nangka dipanaskan dengan $\mathrm{H}_{2} \mathrm{SO}_{4}$ sehingga terjadi destruksi yang berfungsi untuk mengubah protein, karbohidrat dan lemak menjadi unsurunsurnya yaitu elemen $\mathrm{C}, \mathrm{H}$ dan $\mathrm{N}$ (Sudarmadji.S.,1989 dalam Pratiwi, 2011). Langkah selanjutnya yaitu metode delignifikasi, bertujuan untuk melarutkan kandungan didalam suatu bahan sehingga mempermudah proses pemisahan lignin dengan serat. Penggunaan larutan basa atau alkali seperti penggunaan $\mathrm{NaOH}$ dapat digunakan untuk membantu pemisahan lignin dari serat selulosa (Kurniaty, dkk.,2017). Langkah terakhir yaitu pengabuan. Penentuan kadar abu adalah dengan mengoksidasi semua zat organik pada suhu tinggi, yaitu sekitar $500-600^{\circ} \mathrm{C}$ selama 3 jam dan kemudian melalukan penimbangan zat yang tertinggal setelah proses pembakaran (Sudarmadji.S.,1989), sehingga diperoleh perhitungan kadar selulosa dami nangka dapat dilihat pada tabel 2.

Dari tabel 2 diketahui bahwa kadar selulosa dari dami nangka adalah 5.73\%. Hasil dapat dilihat pada tabel 2 dibawah ini :

\section{Hidrolisa Selulosa Dami Nangka dan Uji Gula Reduksinya secara kualitatif dan secara Spektrofotometri}

Dari hasil hidrolisis selulosa dami nangka dengan menggunakan $\mathrm{HCl} \mathrm{30 \%} \mathrm{maka} \mathrm{dihasilkan}$ sirup glukosa. Setelah diidentifikasi secara kualitatif yang bertujuan untuk membuktikan ada tidaknya gula reduksi (glukosa), dengan penambahan reagen Benedict menunjukkan hasil positif bahwa selulosa dami nangka mengandung glukosa dengan terbentuknya endapan merah bata. Gula reduksi dengan reagen benedict akan terjadi reaksi oksidasi, dimana glukosa dapat mereduksi ion $\mathrm{Cu}^{2+}$ dari kupri sulfat menjadi ion $\mathrm{Cu}^{+}$yang kemudian mengendap sebagai $\mathrm{Cu}_{2} \mathrm{O}$ yang berupa endapan merah bata (Poedjadi, 1994).

Setelah diidentifikasi secara kualitatif dengan reagen benedict, selanjutnya uji gula reduksi ditentukan kandungan sirup glukosa dengan metode Nelson-Somogyi, ditentukan dengan mengukur hubungan antara absorbansi dengan berbagai panjang gelombang, dengan menggunakan alat spektometer visible yang dilakukan dengan panelis yang teruji sehingga diperoleh pada panjang gelombang ( $\left.\lambda_{\text {maksimum }}\right) 761$ $\mathrm{nm}$, dapat dilihat pada gambar 1 .

Setelah itu larutan glukosa standar diukur absorbansinya pada berbagai konsentrasi dengan panjang gelombang maksimum $761 \mathrm{~nm}$, kurva hubungan antara absorbansi dan konsentrasi glukosa standar dapat dilihat pada gambar 2. 
Tabel 2. Data Perhitungan Kadar Serat Dami Nangka

\begin{tabular}{|c|c|c|c|c|c|}
\hline Perulangan & $\begin{array}{c}\text { Isolasi Dami } \\
\text { Nangka (g) }\end{array}$ & $\begin{array}{c}\text { Berat } \\
\text { Abu (g) }\end{array}$ & Berat Hilang & $\begin{array}{c}\text { Kadar serat } \\
\text { kasar (selulosa) }\end{array}$ & $\begin{array}{c}\text { Rata- } \\
\text { rata }\end{array}$ \\
\hline I & 5 & 0.463 & $4.573 \mathrm{~g}$ & $5.23 \%$ & $5.73 \%$ \\
\hline II & 5 & 0.419 & $4.581 \mathrm{~g}$ & $6.11 \%$ & \\
\hline III & 5 & 0.433 & $4.567 \mathrm{~g}$ & $5.85 \%$ & \\
\hline
\end{tabular}

\section{Absorbansi Larutan Glukosa pada berbagai Panjang Gelombang}

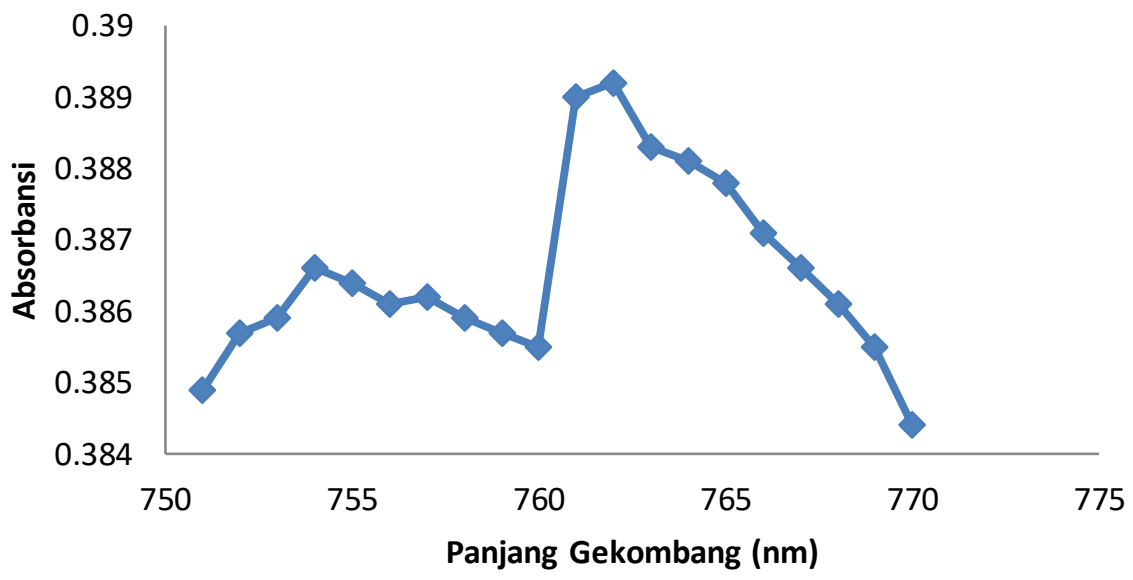

Gambar 1. Grafik absorbansi larutan glukosa standar pada penentuan panjang gelombang maksimum

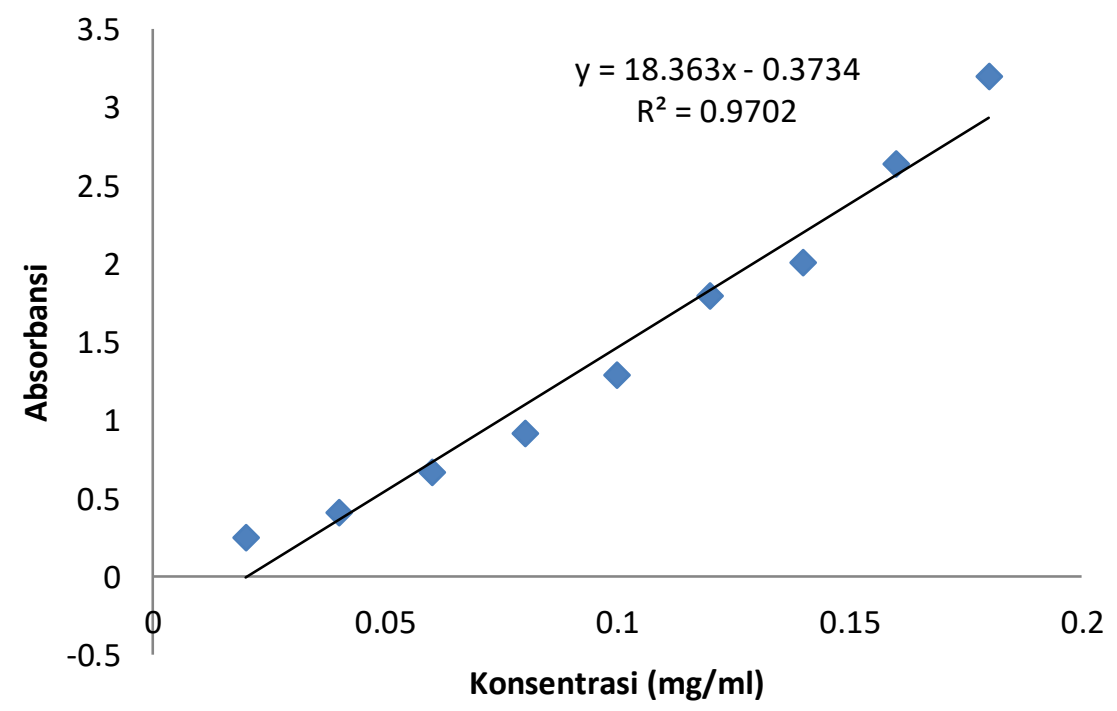

Gambar 2. kurva hubungan antara absorbansi dan konsentrasi glukosa standar 
Tabel 3. Tabel Hasil Perhitungan Kadar Gula Reduksi Berdasarkan Absorbansi Glukosa Hasil Hidrolisis Selulosa Dami Nangka

\begin{tabular}{|c|c|c|c|c|}
\hline Perulangan & Absorbansi & $\begin{array}{c}\text { Konsentrasi } \\
\text { Glukosa } \\
\text { (mg/ml) }\end{array}$ & $\begin{array}{c}\text { Kadar } \\
\text { Glukosa (\%) }\end{array}$ & $\begin{array}{c}\text { Kadar } \\
\text { Glukosa } \\
\text { Rata-rata }\end{array}$ \\
\hline I & 0.3811 & 0.0479 & 2.40 & $2.47 \%$ \\
\hline II & 0.4497 & 0.0517 & 2.59 & \\
\hline III & 0.3887 & 0.0484 & 2.47 & \\
\hline
\end{tabular}

\section{Hasil penetapan Kadar Glukosa Reduksi}

Analisa selanjutnya adalah menentukan hasil penetapan kadar glukosa dengan metode Nelson- Somogyi. hasilnya dapat dilihat pada tabel 3. Berdasarkan tabel 3 dari perhitungan dengan metode Nelson-Somogyi didapatkan nilai kadar glukosa dami nangka yaitu $2.47 \%$. Dengan metode Nelson-Somogyi, dimana metode ini digunakan untuk mengukur kadar gula reduksi dengan menggunakan pereaksi tembaga arsenomolibdat. $\mathrm{Cu}^{2+}$ direduksi menjadi $\mathrm{Cu}^{+}$yang kemudian dilarutkan dengan arsenomolibdat menjadi molibdenum berwarna biru (Sudarmadji, 1984 dalam pratiwi,2011). Intensitas warna yang terbentuk menunjukkan banyaknya gula pereduksi yang terdapat dalam sampel, karena konsentrasi arsenomolibdat yang tereduksi sebanding dengan konsentrasi tembaga (1) oksida (Cu2O), sedangkan konsentrasi Cu2O sebanding dengan konsentrasi gula pereduksi (Nelson,1994 dalam Alkayyis,2016). Dari penelitian ini pada tabel 2 diperoleh kadar serat selulosa sebesar $5.73 \%$ untuk $5 \mathrm{~g}$ dami nangka kering. Pada tabel 3 Kadar glukosa hasil hidrolisis selulosa sebesar $2.47 \%$.
Hal tersebut menunjukkan bahwa selulosa dari dami nangka dapat menjadi salah satu alternatif pengganti gula pasir.

\section{Pengujian Organoleptik terhadap Manisan kelapa}

Pada pembuatan manisan, digunakan buah kelapa. Larutan gula berupa campuran gula pasir dan larutan sirup glukosa dengan perbandingan 1:0, 1:1, 1:2, dan 1:3. Hasilnya dapat dilihat pada tabel 4. Berdasarkan uji organoleptik yang dilakukan terhadap 15 orang panelis yang dilakukan, diketahui bahwa rasa manisan buah kelapa dengan gula pasir lebih disukai oleh panelis dibandingkan dengan manisan dari sirup glukosa yaitu perbandingan 1:0. Untuk warna dan aroma pada manisan kelapa diperoleh dari buah kelapa itu sendiri, dari uji organoleptik untuk warna dan aroma, masing-masing diketahui bahwa perbandingan 1:0 dan 1:3 adalah manisan yang paling disukai panelis. Hal ini menjelaskan bahwa sirup glukosa yang dihasilkan dapat digunakan sebagai pemanis alternatif pengganti gula pasir, sehingga dapat mengurangi pemakaian gula pasir.

Tabel 4. Nilai Organleptik Manisan bualh kelapa

\begin{tabular}{|c|c|c|c|c|}
\hline Variabel & \multicolumn{3}{|c|}{ Gula Pasir : Sirup Glukosa Hasil Hidrolisa Dami Nangka } \\
\hline & $1: 0$ & $1: 1$ & $1: 2$ & $1: 3$ \\
\hline Rasa & 4.13 & 2.53 & 2.80 & 2.93 \\
\hline Warna & 3.93 & 3.13 & 3.20 & 3.33 \\
\hline Aroma & 4.06 & 3.00 & 3.00 & 2.93 \\
\hline
\end{tabular}




\section{KESIMPULAN}

Dari hasil penelitian dapat disimpulkan bahwa kadar selulosa dari dami nangka adalah $5.73 \%$, kadar selulosa hasil hidrolisis selulosa dami nangka adalah $2.47 \%$, dan uji organoleptik menyatakan bahwa sirup glukosa hasil hidrolisis memberikan kemanisan pada pembuatan manisan dari buah kelapa dan dapat dimanfaatkan sebagai alternatif pengganti gula pasir.

\section{UCAPAN TERIMA KASIH}

Penulis mengucapkan terimah kasih yang sebesar-besarnya kepada rekan-rekan maupun Fakultas MIPA USU yang telah memberi fasilitas dalam melaksanaka penelitian.

\section{DAFTAR PUSTAKA}

Al-kayyis,K.H., dan Susanti,H. 2016. Perbandingan Metode Somogyi - Nelson dan Anthrone-Sulfat pada Penetapan Kadar Gula Pereduksi dalam Umbi Cilembu (Ipomea batatas L.) Jurnal Farmasi Sains dan Komunitas 13 (2) : 81-89

Girindra, A.1990. Biokimia 1. Jakarta : PT Gramedia.

Fengel, D. 1992. Kayu, Kimia, Ultrastruktur, Reaksi-Reaksi. Yogyakarta: Gadjah Mada Press.

Kurniaty,I.,Habibah,U., $\quad$ Yustiana,D., $\quad$ dan Isnaini,F.M. 2017. Proses Delignifikasi $\mathrm{NaOH}$ dan Amonia $\left(\mathrm{NH}_{3}\right)$ pada Tempurung Kelapa. Jurnal Integral Proses V0l.6,No.4: 197-201.

Nelson,N., 1994. A photometric adaptation of the Somogyi method for the determination of glucose. Journal Biol. Chem 153(2), 375379.

Pratiwi, D. 2011. Pemanfaatan Sirup Glukosa Hasil Hidrolisa Selulosa dari Kulit Buah Sukun (Artocarpus altilis) dengan $\mathrm{HCl} 30 \%$ untuk Pembuatan Manisan Jambu Biji (Psidium guajnava L.) dengan Variasi Konsentrasi. Skripsi S-1. Jurusan Kimia. Medan: FMIPA USU.

Poedjadi,A.1994.Dasar-Dasar Biokimia. Penerbit UI Press. Jakarta : UI-Press. 39-41

Sari,F.M., 2012.Pembuatan Manisan Mangga (Mangifera indica L.) dengan Memanfaatkan Sirup Glukosa hasil
Hidrolisis Selulosa Kulit Buah kuini (Mangifera odorata G.) Menggunakan $\mathrm{HCl}$ 30\% . Skripsi S-1. Jurusan Kimia. Medan: FMIPA USU.

Sugiarta.2003. Pengaruh Asam Sitrat dan Gula terhadap Mutu Selai dari Dami Nangka Varietas Nangka Kunir (Artocarpus heterophyllus). Institut Teknologi Bandung. Jawa Barat.

Sulaiman,H.A.,1996. Dasar-dasar Biokimia untuk Pertanian. Medan: USU Press.

Tarmizi, 2011. Pengaruh Tingkat Pencemaran Daging Buah dengan Dami Nangka terhadap Mutu Lembaran Nangka (Artocarpus heterophyllus) yang dihasilkan. Skripsi Fakultas Teknologi Pertanian Universitas Andalas, Padang.

Wijayanti, L.2005.Pengaruh Temperatur dan Durasi Inkubasi Kadar Alkohol dari Fermentasi Glukosa hasil Hidrolisis Rumput Gajah (Pennisetrum purperum) dengan $\mathrm{HCl} 3 \%$ menggunakan Saccharomyces cereviciae. Skripsi S-1. Jurusan Kimia. Medan: FMIPA USU. 